BOŽICA SLAVKOVIĆ, stipendista Ministarstva prosvete i nauke

Institut za savremenu istoriju

UDK 339.9(497.1:496.5)"1945/1948"

Beograd, Trg Nikole Pašića 11

327(497.1:496.5)"1945/1948"

\title{
JUGOSLOVENSKO-ALBANSKI EKONOMSKI ODNOSI 1945-1948. Planovi i saradnja
}

\begin{abstract}
APSTRAKT: Članak se, na osnovu istraživanja u Arhivu Jugoslavije i odgovarajuće literature, bavi ekonomskom saradnjom, njenim obim i vrstu, kao i političkim uslovima za stvaranje ekonomskih odnosa Jugoslavije i Albanije u periodu 1945-1948. U radu je predstavljen i bilans ostvarene saradnje.
\end{abstract}

Ključne reči: Jugoslavija, Albanija, ekonomija, ugovori

Odnosi KP Jugoslavije i KP Albanije, koji su bili ustanovljeni u toku Drugog svetskog rata, posle oslobođenja dobili su novu dimenziju. Stvarano je euforično raspoloženje o međusobnom bratstvu, o neraskidivom prijateljstvu i saradnji. ${ }^{1}$ I pored toga što posle oslobođenja još uvek nije bila stala na svoje noge, jugoslovenska država je otpočela sa pružanjem pomoći Albaniji, koja je kao mala zemlja bila izložena strahovitim stradanjima u toku rata, a posledice su se osećale u svim segmentima života. ${ }^{2}$

Još pre zvaničnog priznanja albanske države, ${ }^{3}$ Jugoslavija je 20. februara 1945. sklopila dva ugovora sa Albanijom. Prvi ugovor je imao oblik vojnog saveza za zajedničku borbu protiv nemačkih okupacionih snaga, što je trebalo da se produži i u posleratnim godinama. Drugi ugovor je regulisao privrednu saradnju, koja je podrazumevala ukidanje carinske granice, razmenu robe između Jugoslavije i Albanije i međusobno konsultovanje o sklapanju ugovora sa trećim zemljama. Obe zemlje su bile izjednačene u pravima u svim njihovim vodama i pristaništima. ${ }^{4}$

${ }^{1}$ Arhiv Jugoslavije (dalje: AJ), AC SKJ, Ministarstvo spoljne trgovine, 9, 1/111, 21. april 1945, AC SKJ, Ministarstvo spoljne trgovine, 9, 1/1-37, 14. novembar 1945. Baškimi.

${ }_{2}^{2}$ AJ, AC SKJ, Ministarstvo spoljne trgovine, 9, 1/2-38, 16. septembar 1945.

${ }^{3}$ Jugoslavija je bila prva država koja je priznala Albaniju, 29. aprila 1945.

${ }^{4}$ Đ. Borozan, Velika Albanija. Porijeklo. Ideje. Praksa, Beograd 1995, 514; AJ, Arhiv Josipa Broza Tita, Kabinet Maršala Jugoslavije, dok. 1-3-v/11. 
U septembru 1945. Albanija i Sovjetski Savez potpisali su sporazum po kojem su Sovjeti obezbeđivali žito i tehničke stručnjake za naftnu industriju i rudarstvo, a Albanija je zauzvrat trebalo da šalje u SSSR duvan, sušeno voće, rudu bakra i naftu. ${ }^{5}$

I pored dobre volje za saradnjom, do kraja 1945. splasnulo je oduševljenje za bratstvo i jedinstvo sa Jugoslavijom. Albancima je zamerano da nedovoljno cene ekonomsku pomoć Jugoslavije, a na drugoj strani da ne izvršavaju svoje obaveze prema Jugoslaviji. ${ }^{6}$ Kod dela albanskog rukovodstva bilo je shvatanja da je pomoć koju dobijaju od Jugoslavije u stvari sovjetska pomoć, tj. da SSSR pruža pomoć Albaniji posredstvom Jugoslavije. ${ }^{7}$

Konačno, na Petom plenumu CK KPA februara 1946. odlučeno je da se Albanija okrene saradnji sa Jugoslavijom i da se oslobodi oportunista. List Luftetari je istakao „dva naroda i dve vojske, koje su se vezale krvlju svojih najboljih sinova u velikoj antifašističkoj borbi odlučili su da zajedno koračaju i na putu obnove, boljeg života i mira." ${ }^{8}$

Nosioci nove privredne politike, ipak, nisu pravovremeno uočili značaj razlika između ekonomske organizacije i politike u SSSR-u i Albaniji kao ni razlike u Jugoslaviji i Albaniji. Jugoslavija je za čitavu godinu dana bila odmakla i u Albaniji je trebalo krenuti putem kojim je Jugoslavija već prošla sredinom 1945. S druge strane, sovjetski stručnjaci nisu dovoljno poznavali albanske prilike i zato svoje znanje nisu mogli da prilagode albanskim potrebama.

U albanskoj privredi vladala je haotična situacija. Usled dotadašnje privredne politike, narod nije gotovo ništa dobio od nove vlasti, dok je agrarna reforma, iako je bio uložen veliki kapital, obuhvatala tek deo stanovništva, pa je i taj kapital bio slabo iskorišćen. ${ }^{9}$ Loše žetve, osim toga, izazvale su nedostatak hrane. Prinudne mere, kao što je bila zaplena žita, ${ }^{10}$ nisu mogle da nadomeste oskudicu. ${ }^{11}$

U maju 1946. potpisan je sporazum o trgovinskoj razmeni i plaćanju između Jugoslavije i Albanije: trebalo je voditi računa o tome da izvoz stigne na vreme i jednoj i drugoj strani. Liste roba su se mogle dopunjavati i menjati u vreme trajanja sporazuma. Cene ovoj robi trebalo je da određuje mešovita komisija. Obe strane bile su saglasne da saldo može iznositi najviše 20.000.000 dinara. Ovaj sporazum je zamenjivao ugovor od 25. februara

\footnotetext{
${ }^{5}$ R. Krempton, Balkan posle Drugog svetskog rata, Beograd 2003, 74.

${ }^{6}$ Srbi i Albanci u 20. veku, Beograd 1991, 379.

${ }^{7}$ M. Komatina, Enver Hodža i jugoslovensko-albanski odnosi, Beograd 1995, 47-48.

${ }^{8}$ AJ, AC SKJ, Ministarstvo spoljne trgovine, 9, 1/1-45, 23. februar 1946, list Luftetari.

${ }^{9}$ AJ, AC SKJ, Ministarstvo spoljne trgovine, 9, 1/1-43, 7. februar 1946, izveštaj J. Đerđe.

${ }^{10}$ Tada su seljaci smeli da za svoje potrebe zadrže $15 \mathrm{~kg}$ pšenice po članu domaćinstva.

${ }^{11}$ P. Bartl, Albanci. Od srednjeg veka do danas, Beograd 2007, 238.
} 
1945. i trebalo je da se primenjuje do 31. decembra 1946. Narodna banka FNRJ trebalo je da otvori beskamatni račun u dinarima na ime Albanske državne banke, na koji bi se polagala protivvrednost robe uvezene iz Albanije u Jugoslaviju. Preko ovog računa trebalo je da se vrše i isplate $u$ Jugoslaviji po nalozima Albanske državne banke za robu izvezenu iz Jugoslavije u Albaniju. Nalozi za isplatu imali su da glase na dinare. ${ }^{12}$

Da su odnosi Jugoslavije i Albanije bili na uzlaznoj liniji pokazuje i dolazak Enver Hodže i albanske delegacije u Beograd. Za vreme posete, 1. jula 1946, potpisani su sporazumi o privrednoj saradnji, plaćanjima i kreditima. Jugoslavija se obavezala da podrži razvoj industrije i privrede Albanije pružanjem tehničke pomoći i slanjem eksperata, davanjem informacija i ustupanjem dokumentacije, obukom albanskih specijalista. Bilo je predviđeno da se albanski stručnjaci obučavaju u Jugoslaviji, a da se Albancima putem kredita omogući da u Jugoslaviji kupe mašine i tehničku opremu. Vlada FNRJ se obavezala da odobri vladi NR Albanije kredit od 1.200.000 dolara za kupovinu robe u Jugoslaviji prema listi koja je trebalo da bude određena zajedničkim sporazumom do iznosa od 600.000 za plaćanje raznih usluga koje mogu ugovoriti u Jugoslaviji na račun albanske vlade, albanske ustanove, preduzeća i lica. Vlada NRA trebalo je da isplati ovaj kredit isporukama robe FNRJ. ${ }^{13}$

Postignut je dogovor o formiranju mešovitih jugoslovensko-albanskih preduzeća (analogno sovjetsko-jugoslovenskim iskustvima) na paritetnoj osnovi koja bi se brinula o razmeni robe, eksploataciji albanskog rudnog bogatstva i transportnih potencijala. To su bila: Društvo za gradnju i eksploataciju železnica, Društvo za ekstrakciju i proizvodnju nafte, Društvo za istraživanje rudnika, za eksploataciju i obradu rude, Društvo za elektrifikaciju, Društvo za pomorsku plovidbu, Trgovačko društvo za uvoz i izvoz, Albansko-jugoslovenska banka. ${ }^{14}$

Jugoslavija je trebalo da uplati $50 \%$ osnovnog kapitala za društva. ${ }^{15}$ Svako društvo je imalo upravni odbor od 8 članova i nadzorni odbor od 4 člana, pri čemu su mesta podeljena paritetno između predstavnika jugoslovenskog i predstavnika albanskog kapitala. Sedište svakog društva bilo je u Tirani. Onde gde je to bilo potrebno predviđeno je sedište Glavne filijale u Beogradu. Svako društvo je trebalo da traje 30 godina i to vreme se moglo

${ }^{12}$ AJ, Predsedništvo vlade FNRJ, dok. 50-80-85.

${ }^{13}$ AJ, Fond Predsedništva vlade FNRJ 50, k. 49.

${ }^{14}$ AJ, Komisija za međunarodne veze CK SKJ, 507/9, 1/1-1-126.

${ }^{15}$ Uplata je izvršena u 2 rate i to: Albansko-jugoslovenskom društvu za gradnju i eksploataciju železnica - 37.500.000 dinara, Društvu za istraživanje i eksploataciju nafte 25.000.000, Društvu za istraživanje i eksploataciju rudnog blaga - 12.500.000, Društvu za elektrifikaciju - 12.500.000, Društvu za uvoz i izvoz - 6.250.000, Albansko-jugoslovenskoj banci - 37.500.000 dinara. Ukupno: 131.250.000 dinara. 
produžiti na periode od po 5 godina, ali bi albanska vlada po isteku roka od 30 godina imala pravo otkupa jugoslovenskog dela kapitala. Izričito je predviđena mogućnost da se društvo može likvidirati i pre isteka ovog roka, ako o tome donesu odluku predstavnici jugoslovenskog i albanskog dela kapitala.

Sami sporazumi predviđali su uglavnom paritetne obaveze. Dodatni protokoli koji su se odnosili na određene objekte i radove regulisali su jednostrane obaveze FNRJ što je bio jedinstven primer u ugovorima ove vrste. U tim protokolima FNRJ se obavezala da će: prilikom izgradnje železničkih pruga odobriti učešće svojih građevinskih preduzeća za ove radove kao i mehanizaciju i materijal, izuzev pragova i običnog građevinskog materijala; $\mathrm{u}$ industriji nafte, na izgradnju rafinerija za prečišćavanje nafte kao i izgradnju jedne hidrocentrale za potrebe industrije nafte; $u$ elektroprivredi, na izgradnju hidrocentrale za potrebe grada Tirane. Za NR Albaniju sporazumi su predviđali da u neka od zajedničkih društava unese postojeće investicije ili već izvršene radove.

U Tirani je 9. jula 1946. sklopljen Ugovor o prijateljstvu i uzajamnoj pomoći. On je trebalo da „potvrdi ono nerazrušivo krvno bratstvo koje je stvoreno u velikoj oslobodilačkoj zajedničkoj borbi protiv zajedničkog neprijatelja, on će samo potvrditi rešenost naroda obeju prijateljskih zemalja da i ubuduće zajednički brane svoju slobodu i nezavisnost“" ${ }^{16}$

U toku privrednih pregovora postavilo se pitanje utvrđivanja kursa između dinara i novog albanskog franka. Na osnovu mišljenja albanskog ministra finansija od 15. jula 1946. određen je kurs od 6.12 novih albanskih franaka za 100 dinara, to jest 16.34 dinara iznosio je jedan albanski franak. Ovaj kurs bio je utvrđen na bazi jugoslovenske otkupne cene za zlato i otkupne cene za zlato novog albanskog franka. Zamena novca je trajala od 15. do 24. jula, a maksimum za isplatu bilo je 1.000 novih franaka. U početku menjanja novca na tržištu je vladao haos, jer se pojavilo mnogo crnoberzijanaca i špekulanata. Posle donošenja smrtnih presuda za takva dela prvo u Skadru, pa u Valoni, stanje se izmenilo i stabilizovalo. ${ }^{17}$

Vlada Albanije je, posle zvaničnog potpisivanja dokumenta o dobijanju pomoći od Jugoslavije, donela budžet za 1946/47. u iznosu od 1.136.067.300 albanskih franaka. To je bio prvi planski budžet koji je odgovarao potrebama albanskog naroda. ${ }^{18}$

Krajem 1946. nastavljeno je povezivanje privreda dveju zemalja. Dana 27. novembra u Beogradu su potpisani ugovori o usklađivanju privrednih planova, o carinskoj uniji i izjednačenju valuta između ove dve zemlje.

\footnotetext{
${ }^{16}$ AJ, Fond Tanjuga, 112-796-797, jul 1946.

${ }_{17}^{17}$ AJ, Komisija za međunarodne veze CK SKJ, 507/9, 1/1-1-126.

${ }^{18}$ AJ, Fond Tanjuga, 112-797-799, 4. avgust 1946.
} 
Jugoslovenska vlada se obavezala da će uvozom robe u Albaniju pomoći njenoj vladi da obezbedi potrebnu robnu bazu za održanje vrednosti albanskog leka na visini jugoslovenskog dinara. Opticaj novčanica u NRA trebalo je da bude srazmeran visini novčaničnog otkupa u FNRJ na osnovu broja stanovnika i ekonomske snage obeju zemalja. Obe vlade obavezale su se da u roku od mesec dana ukinu carinsku granicu i carine između dve zemlje, stvarajući jedinstvenu carinsku teritoriju. ${ }^{19}$ Da bi se osigurala efikasna primena odredaba, trebalo je da na teritoriji NRA bude obrazovana albanskojugoslovenska mešovita carinska komisija. ${ }^{20}$ Ovaj ugovor je trebalo da traje 30 godina. Vlada FNRJ se obavezala da će pomoći vladi NRA da otkloni nasleđene privredne i tehničke zaostalosti i da poboljša životni standard masa. Stope dobiti i stope poreza na promet od proizvoda koje su važili u FNRJ, trebalo je da važe i u NR Albaniji. Obe države su mogle da stupaju u trgovinske odnose sa trećim zemljama. Jugoslovenska vlada je trebalo da obezbedi Albaniji potrebne devize i uvoz materijala, mašina i postrojenja. Trgovinu je trebalo da obavlja Jugoslovensko-albansko društvo za uvoz i izvoz ili izvozna odnosno uvozna preduzeća FNRJ. ${ }^{21}$ Primena je trebalo da otpočne početkom 1947.

Albanija je zahvaljujući jugoslovenskoj pomoći dobila nove fabrike i popravljene su stare, ${ }^{22}$ a izgrađena je i železnička pruga. ${ }^{23}$ Jugoslavija je po- $^{2}$ mogla i izgradnju hidrocentrale Velika Selita kod Tirane koja je trebalo da snabdeva električnom energijom industriju Tirane i Drača, kao i izgradnju vodovoda za snabdevanje stanovništva ova dva grada. Radove je izvodilo Albansko-jugoslovensko električno društvo preko jugoslovenskog preduzeća Hidrogradnja iz Beograda, koje je izdvojilo najbolje mašine, transportna sredstva, alat, radionice i kadar. ${ }^{24}$ PTT saobraćaj je počeo da se razvija, ${ }^{25}$ struja je ulazila $u$ albanske domove. ${ }^{26}$ Albanski seljaci dobili su potporu države u svom poljoprivrednom radu, ${ }^{27}$ agrarnom reformom je ukinut feudalni

\footnotetext{
${ }^{19}$ AJ, Komisija za međunarodne veze CK SKJ, 507, 1/1-1-126.

${ }^{20}$ V. Dedijer, Jugoslovensko-albanski odnosi 1939-1948, Beograd 1949, 174.

${ }^{21}$ AJ, Fond Predsedništva vlade FNRJ 50, k. 48, Fond Komisije za međunarodne veze CK SKJ, 507, 1/1-1-126.

${ }^{22}$ V. Dedijer, n. d., 182-183. AJ, Fond Tanjuga, 18. avgust 1947, 112-817-818. AJ, Fond Tanjuga, 29. oktobar 1947, 112-823-824.

${ }^{23}$ Izgradnja pruga Drač-Pećin i Drač-Elbasan koju je gradilo Albansko-jugoslovensko društvo za izgradnju železnica. AJ, Fond Tanjuga 112-807-808, 112-809-810, $112-$ 812-813, 112-824-825, Ministarstvo spoljne trgovine, 9, dok. 1/1-137, 1/3-66.

${ }^{24} \mathrm{~V}$. Dedijer, $n$. d., 187.

${ }^{25}$ Uvedena automatska telefonska centrala. AJ, Fond Tanjuga, 112-817-818, 112$828-829$.

${ }^{26}$ AJ, Fond Predsedništva Vlade FNRJ 50, k. 48, 15. avgust 1946.

${ }^{27}$ AJ, Fond Tanjuga, 112-792-793, 6. mart 1946; 112-792-793, 15. mart 1946; 14. mart 1947, 112-807-808; 18. april 1947, 112-810-811; R. Krempton, n. d., 70-71.
} 
sistem u zemlji, ${ }^{28}$ radnička klasa je izašla iz povoja, ${ }^{29}$ osnivane su zadruge, ${ }^{30}$ pojedinci su odlazili na stručno usavršavanje u Jugoslaviju, gde su u fabrikama tretirani kao polukvalifikovani radnici i dobijali platu. ${ }^{31}$ Takođe, albanskim studentima bilo je omogućeno da studiraju u Jugoslaviji uz obezbeđena sredstva. ${ }^{32}$ Albansko stanovništvo dobijalo je i pomoć u žitu, što je bilo neophodno za tako siromašnu zemlju.

Ta pomoć stizala je i van sporazuma u slučajevima kada su albanski rukovodioci to zahtevali ili kada je to bilo neophodno. U periodu 22-23. oktobar 1946. u Albaniji su se desile katastrofalne poplave. ${ }^{33}$ Albanija je obavestila Unru, ali od nje nije očekivala efikasniju pomoć. ${ }^{34}$ Prva pomoć postradalima došla je iz Jugoslavije. ${ }^{35}$

I pored bezrezervne jugoslovenske pomoći Albaniji, postojalo je izvesno nepoverenje albanskih rukovodioca prema Jugoslaviji. Moguće je da su to bile one prirodne rezerve malog u odnosu na velikog, sukobi kroz istoriju, težnja Albanaca za nacionalnim ujedinjenjem i pretvaranja Albanije u značajan faktor balkanske strategije. ${ }^{36}$ Jugoslovenski predstavnici u Albaniji primećivali su da su se neki albanski rukovodioci sve više okretali SSSR-u i da su sovjetski stručnjaci sve masovnije dolazili u Albaniju, a i da je albanska

${ }^{28}$ Radi konsolidovanja države posle rata je sprovedena agrarna reforma, do tada najobimnija u Albaniji. Oduzeto je 173.000 hektara zemljišta (ukupna obradiva površina 1938. u Albaniji iznosila je 292.000 hektara). Od toga je 155.000 hektara dodeljeno seljacima bezemljašima, a ostatak je iskorišćen za formiranje državnih dobara.

${ }^{29}$ AJ, Fond Tanjuga, 112-788-789, 25. avgust 1945, Komisija za međunarodne veze CK SKJ, 507/9, 1 / 2-38-108.

${ }^{30}$ AJ, Fond Tanjuga, 3. oktobar 1947, 112-821-822. Pre rata zadrugarstvo nije postojalo, dok je po oslobođenju zadružni pokret dobio široke razmere. Tokom 1947. u zemlji je bilo ukupno 25 potrošačkih, 300 nabavljačko-potrošačkih, 69 zanatskih, 6 ribarskih i 21 seljačka radna zadruga. U potrošačkim zadrugama učlanjeno je bilo $90 \%$ gradskog stanovništva, a nabavljačko-potrošačkim $37 \%$ seoskog stanovništva. Zanatske zadruge obuhvatale su $52 \%$ zanatlija.

${ }^{31}$ AJ, Ministarstvo rada FNRJ, dok. 25-84-213. Mnogi omladinci iz NRA bili su uposleni kao učenici u privredi u jugoslovenskim preduzećima. Dobijali su na ime ishrane i smeštaja u domu 600 dinara i 300 dinara džeparca.

${ }^{32}$ Đ. Borozan, $n$. d., 515.

${ }^{33}$ Porušeno je nekoliko stotina mostova, prekinut je saobraćaj od Tirane sa Skadrom, Korčom i Piškopejom. Desetine hiljada ljudi ostalo je bez domova. Sela u okolini Ljušnje u srednjoj Albaniji su najviše nastradala. Uništen je deo roda kukuruza od te godine. Prema obaveštenjima N. Spirua, bilo je 50.000 oštećenih lica u celoj Albaniji.

${ }^{34}$ AJ, Fond Predsedništva vlade FNRJ, 50, k. 48, poslala je 300.000 dolara. Fond Tanjuga, 112-801-802, 15. novembar 1946.

${ }^{35} \mathrm{U}$ Jugoslaviji je skupljeno 52 miliona dinara i u robi isporučeno postradalom albanskom narodu. - AJ, Ministarstvo spoljne trgovine, dok. 1/1-37; Fond Tanjuga, 112-801-802.

${ }^{36}$ B. Petranović, Jugoslavija, velike sile i balkanske zemlje 1945-1948, Beograd 1994, $113-114$. 
štampa popularisala SSSR više nego Jugoslaviju. ${ }^{37} \mathrm{Na}$ terenu Albanije su već izbijale sitne jugoslovensko-sovjetske čarke koje su bile prvi signali sukoba. Sovjetsko rukovodstvo je prevashodno smatralo ispravnim da Albanija bude pod okriljem Jugoslavije sve dok Jugoslavija verno sledi sovjetsku državu. Kada je Jugoslavija počela da pokazuje znake samostalnosti u svojoj politici prema Albaniji, usledila je reakcija Sovjetskog Saveza. ${ }^{38}$ Enver Hodža je posetio Moskvu u julu 1947. ${ }^{39}$ Albanski vođa se vratio iz sovjetske prestonice sa najboljim utiscima o prijateljstvu naroda SSSR-a: „Ono što smo tražili odmah je prihvaćeno i sovjetska vlada je obećala da će nam pružiti pomoć za podizanje naše privrede i života našeg naroda. Sovjetska vlada će nas pomagati time što će nam dati na kredit fabrike i traktore i pomoći će nas na kulturnom, prosvetnom i drugim poljima". ${ }^{40} \mathrm{Na}$ preke poglede suseda, odgovarao je pohvalama o saradnji sa Jugoslavijom, mada je jasno bila uočena prosovjetska linija.

U napetoj i nepoverljivoj atmosferi nastavljeni su ekonomski i drugi odnosi Jugoslavije i Albanije. Albanska vlada je donela uredbu o zameni albanskog franka za lek koji je ravan dinaru po kursu $1: 9,{ }^{41}$ usvojila niz drugih uredbi i sprovela druge mere za osiguranje stabilnosti nove valute. Prema uredbi, zamena novca vršila se u neograničenim količinama. Zahvaljujući ovom izjednačenju, „državni privredni sektor je postao mnogo jači, lek je postao jaka moneta“. ${ }^{42}$ Međutim, realizacija trgovinskih sporazuma i saradnja dveju država bila je praćena brojnim nepravilnostima i nedostacima. U jednom izveštaju se naglašava kako su Albanci remetili isporuku jugoslovenskih artikala stavljajući neumesne primedbe (loš kvalitet, slaba ambalaža, neslanje faktura, pitanje reklamacija itd.). Jugoslovenska lista izvoza i uvoza ostvarena je sa 26\%, a albanska sa 21\%. Po mišljenju trgovinskog izaslanika Stojana Divića, albanski stav prema Jugoslaviji u svim privrednim granama bio je nepravilan. Ilustracija toga jeste i primer Dračke luke. Albanci su svakodnevno urgirali za isporuke robe od Jugoslavije, ali nisu mogli da „progutaju“ ni količine koje su im slate nego je svaki brod koji je dolazio stajao po 7 dana u kontrastalijama. Istovar je obavljala samo jedna smena koja je radila 8 sati, a posle se odmarala dok su za to vreme brodovi stajali. Na pristaništu i u luci vladao je haos - roba je bila razbacana, nezaštićena od vremenskih nepogoda. Luka je mogla da primi samo dva broda za istovar. Iz celog albanskog stava, podvlači Stojan Divić, „izbija sitno špekulantsko

\footnotetext{
${ }^{37}$ M. Komatina, n. d., 56.

${ }^{38}$ Isto, 58.

39 Isto, 59.

${ }^{40}$ AJ, Fond Tanjuga, 26. jul 1947, 112-816-817.

${ }^{41}$ AJ, Fond Tanjuga, 112-815-816.

${ }^{42}$ AJ, Ministarstvo spoljne trgovine, 9, dok. 1/1-132.
} 
ćiftinska trgovačka politika i želja da samostalno i nezavisno nastupaju na svetskom tržištu“. ${ }^{43}$ Spiskovi su se radili na brzinu i nepotpuno, pa zato nisu ni mogli biti sklopljeni ugovori sa preduzećima za isporuku robe. Poslovanje Albansko-jugoslovenske banke bilo je nesređeno i osećala se tendencija njenog zaobilaženja.

Generalna direkcija transporta Ministarstva spoljne trgovine obavestila je da su se mašine i delovi fabrike šećera upućeni u Korču istovareni u blatu na otvorenom polju i da su nastupila velika oštećenja. Prihvat robe nije dobro organizovan, a centralni magacin nije ni postojao. Zbog nepoznavanja jezika predstavnici albansko-jugoslovenskih društva često nisu mogli da se snađu u dokumentima koja su pratila robu, pa su odbijali da je prime i upućivali su kamione od jednog mesta na drugo dok ne bi pronašli kome je namenjen. ${ }^{44}$

Jegenije Ahmet, generalni direktor Albansko-jugoslovenskog društva za izvoz i uvoz, ocenio je na konferenciji Impeksa održanoj 17. ili 18. jula da je „Jugoslavija dala kredit, ne zna se da li u spekulativne ili u političke svrhe ali da je Albanija dovoljno jaka da taj kredit i vrati“ ${ }^{45}$

U celini gledano, krajem 1947. postala je jasna tendencija Albanije da se izmakne privrednoj kontroli Jugoslavije. Mišljenja jugoslovenskih stručnjaka u Albaniji bila su ignorisana, a oni sami nazivani saboterima i špekulantima. Takva situacija se nastavila i tokom 1948. Albanci su nastojali da zaobiđu obaveze iz ugovora i da prikriju pomoć Jugoslavije, a kršili su i neke odredbe. ${ }^{46}$

Rad mešovitih društava bio je praćen velikim teškoćama. Promene ponašanja albanske strane pratile su u stopu jugoslovensko-sovjetske nesporazume, koji su sa ekonomskog brzo prelazili na politički teren. Pre svega, albansko ministarstvo je preuzelo upravu nad ovim društvima, pri tom zaobilazeći jugoslovenske rukovodioce. Dvojno rukovođenje društvima stvorilo je nezdrave odnose među Albancima i Jugoslovenima, jer su se i jedni i drugi obraćali direktorima svoje nacionalnosti. Paritetnog rukovođenja u pravom smislu reči nije ni moglo biti jer su jugoslovenski rukovodioci u principu bili stručnjaci za razliku od albanskih.

Jugoslovensko rukovodstvo je tokom aprila pokušalo da odnos dveju država postavi na bazi obostranih interesa, a pre svega da bi se zemlja oslobodila ekonomskog tereta koji je imala prema dotadašnjem prijatelju. Josip Broz Tito je u pismu Enveru Hodži naglasio da se odnosi moraju preispitati, pre svega zbog albanskog nepoverenja u jugoslovenske namere i nepriznavanja

\footnotetext{
${ }^{43}$ AJ, Ministarstvo spoljne trgovine, 16. oktobar 1947, dok. 1/3-20.

${ }^{44}$ AJ, Fond Predsedništva vlade FNRJ, dok. 50-50-109, 17. oktobar 1947.

${ }^{45}$ AJ, Komisija za međunarodne veze CK SKJ, dok. 507/9, 1/1-127-242.

${ }^{46}$ AJ, Fond Predsedništva vlade FNRJ, 50, k. 48, 20. novembar 1947.
} 
jugoslovenske pomoći. ${ }^{47}$ Politbiro CK KPA odbio je u odgovoru J. B. Titu od 23. maja 1948. optužbe Beograda da su se odnosi pogoršali albanskom krivicom. ${ }^{48}$ Josip Đerđa je istakao da je albanska strana iznosila sve jugoslovenske slabosti i greške da bi mogla da dokaže neodrživost odnosa Jugoslavije i Albanije. $^{49}$

Pad saradnje se osećao na svim poljima. Vrhunac je usledio posle donošenja Rezolucije Informbiroa 1948, kada je Albanija pre ugovornog vremena raskinula sve sporazume sa Jugoslavijom. Mada nije bila članica IB-a (E. Hodža navodi da su to sprečili Jugosloveni ${ }^{50}$ ), Albanija je pozvana na tajni sastanak u Bukurešt, kako bi optužnica protiv J. B. Tita bila pojačana njegovim dokazima. ${ }^{51}$

Incidentne situacije su se samo nizale. Obustavljeni su radovi na pruzi Skadar-Titograd i na trasiranju pruge Skadar-Kuks, zato što je te radove izvodilo Jugoslovensko-albansko mešovito društvo. Dana 30. juna obustavljena je isporuka nafte za Jugoslaviju. S druge strane, Albanci su nastojali da prikupe ostatak jugoslovenske robe koji se zatekao u Albaniji. Silom, krađom ili pretnjom pokupljeni su svi planovi i studije iz mešovitih preduzeća, sa gradilišta na železničkoj pruzi, čak i hrana iz magacina za jugoslovenske radnike. ${ }^{52}$ od 5 . do 20 . jula celokupan jugoslovenski kadar se vratio iz Albanije. ${ }^{53}$

Albansko Ministarstvo inostranih poslova predalo je 1. jula poslanstvu FNRJ dve note kojima se tražilo da svi jugoslovenski stručnjaci, savetnici i drugi građani koji se nalaze na radu u Albaniji napuste Albaniju u roku od 48 sati i obaveštavalo da albanska vlada otkazuje sve privredne sporazume i protokole zaključene između dve zemlje. Tom prilikom Albanija nije otkazala jedino Ugovor o prijateljstvu i uzajamnoj pomoći. ${ }^{54}$

Vlada FNRJ je odbacila motive kojima je albanska vlada otkazala privredne sporazume (da je jugoslovenska vlada pomoću njih htela da zagospodari albanskom privredom) i konstatovala da je od čitavog obima

${ }^{47}$ Srbi i Albanci u 20. veku, Beograd 1991, 395.

${ }^{48}$ Isto, 396-397.

${ }^{49}$ M. Komatina, n. d., 86.

${ }^{50}$ E. Hodža, Titoisti, Beograd 1982.

${ }^{51}$ List Baškimi je posvetio punu pažnju Rezoluciji IB, objavivši u julu i avgustu na prvoj strani 65 svojih uvodnika, uvodnika prevedenih iz organa IB-a, raznih govora, vesti albanske telegrafske agencije, telegrama raznih partijskih organizacija upućenih CK KPA i vesti stranih agencija upućenih protiv Jugoslavije, a svega dve vesti uperene protiv anglo-američkih imperijalista. - AJ, Ministarstvo spoljne trgovine, dok. 1/1-161.

${ }^{52}$ M. Komatina, n. d., 87.

${ }^{53}$ AJ, Ministarstvo rada FNRJ, 25, k 96, 1. jul 1948. Do 7. jula Albaniju su napustila 1.024 lica, a u avgustu je na izlaznu vizu čekalo još 1.034 .

${ }^{54}$ AJ, Arhiv Josipa Broza Tita, Kabinet Maršala Jugoslavije, 1-3-v/44, 1. jul 1948. 
privredne saradnje između dve zemlje $81,5 \%$ bilo u korist Albanije, a svega $18,5 \%$ u korist FNRJ. Svrha tih ugovora, po oceni jugoslovenske vlade, bila je da se NR Albaniji s obzirom na nerazvijenost privrede i ratna razaranja pruži što efikasnija bratska pomoć. Vlada FNRJ je uzela na znanje raskid ekonomskih ugovora, iako je prema ugovoru raskid morao da se najavi godinu dana unapred, ali nije prihvatila tezu albanske vlade da su ti ugovori nepostojeći i nevažeći. Takav slučaj, kako je istaknuto, nije zabeležen u istoriji dotadašnjih diplomatskih odnosa i jednostrano se i na najbrutalniji način krši deo ugovora. ${ }^{55}$ Albanska vlada je odgovorila notom od 21. jula u kojoj je na najuvredljiviji način ponovila argumente iz prve note, ocenivši da je Jugoslavija nastojala da privrednom eksploatacijom uništi ekonomsku nezavisnost Albanije. Tvrdila je da je pomenuti jugoslovenski postotak u pomoći Albaniji netačan i da je Jugoslavija ispunila samo 13\% obaveza u prvom polugodištu 1948, dok je albanska vlada izvršila 74,02\%, ali je izrazila spremnost da razgovara o uspostavljanju trgovinskih i ekonomskih odnosa pod uslovom „recipročnosti i jednakosti“. ${ }^{56}$ Poslanstvo FNRJ je po nalogu MIP-a vratilo ovu notu albanskoj strani zbog uvredljivog tona.

Enver Hodža je potpuno promenio politiku prema Jugoslaviji, što se naročito ispoljilo na XI plenumu održanom 13-24. septembra $1948 .{ }^{57}$ kao i na I kongresu KPA 8-22. novembra iste godine. Jugoslavija je optužena za smišljenu politiku porobljavanja Albanije. ${ }^{58}$ Posle kongresa, međutim, ekonomsko stanje $u$ Albaniji se sve više pogoršavalo. Dolaskom sovjetske robe cene namirnica su se stabilizovale, ali su uskoro opet počele da rastu. Narod je govorio da je bolje živeo dok ga je Jugoslavija „pljačkala" nego kada ga Sovjetski Savez pomaže. ${ }^{59}$

Jugoslavija je otkazala ugovor o prijateljstvu i uzajamnoj pomoći 12. novembra $1948 .{ }^{60}$ Branila se protiv kleveta koje su bile upućene na njen račun, pokušavajući da dokaže da je njena pomoć nije ostala samo na obavezama već i da su rezultati vidni. Albanija je do kraja 1947. na osnovu kredita od 2 milijarde zaključila poslove $u$ vrednosti od 1,6 milijardi dinara. Od toga Jugoslavija je isporučila Albaniji materijal u vrednosti od 1,350 milijardi dinara

${ }^{55}$ AJ, Komisija za međunarodne veze CK SKJ, 507/9, 1 / 1-127-242; Borba, 3. jul 1948.

${ }^{56}$ AJ, Komisija za međunarodne veze CK SKJ, 507/9, 1 / 1-127-242, 21. jul 1948.

${ }^{57}$ M. Komatina, n. d., 90.

${ }^{58}$ AJ, Ministarstvo spoljne trgovine, dok. 1/2-119.

${ }^{59}$ Za raspoloženje masa karakterističan je jedan događaj u državnom magacinu u Tirani. Prilikom deobe robe direktor je rekao da će robe biti jer nema Jugoslovena da je kradu. Jedna žena je na to upitala otkud marmelada koja nosi oznaku jugoslovenske fabrike, a druga se našalila: možda je marmelada trockistička, pa će nam naškoditi. - AJ, Ministarstvo spoljne trgovine, 30. decembar 1948, 1/1-239.

${ }^{60}$ M. Komatina, n. d., 93. 
ili $84 \%$ od predviđenog, a ostatak nije realizovan zbog sporog i neblagovremenog postavljanja albanskih zahteva. U isto vreme Jugoslavija je primila iz Albanije vrednost robe $u$ iznosu od 150 miliona dinara, što ne predstavlja odnos ni 1 : 10. Od 3 milijarde kredita iz 1948. Jugoslavija je do kraja juna isporučila 90\% robe koja je stigla u Albaniju ili se nalazila na putu. Albanija nije utvrdila plan izvoza svoje robe za Jugoslaviju, izvezla je u Jugoslaviju za to vreme robe u vrednosti od svega 240 miliona dinara pri čemu se nije htela vezati fiksnim terminima i kvalitetom robe.

U pogledu nižih cena i optužbi da je Jugoslavija izvozila albansku robu u inostranstvo i oduzimala viškove proizvoda albanskih radnih masa, klevete se vide iz činjenice da je FNRJ u 1948. izvozom dela albanskih proizvoda koje je trebalo da dobiju u okviru milijarde leka trebalo da izgubi 52 miliona dinara na razlici između više albanske i niže svetske cene. Pri tom, nisu se uzimale u obzir razlike u kvalitetu, nedostaci u ambalaži, pakovanju itd., usled čega je samo jugoslovensko preduzeće Centroprom izgubilo 17 miliona dinara. Po izjavama predstavnika vlade Albanije u koordinacionoj komisiji uvek je postizana saglasnost, pa i u pogledu cena izvoznih artikala u Albaniju sve do juna, kada još nisu bile definitivno utvrđene cene za svega tri proizvoda. Jugoslavija je uvažavala i znatno više proizvodne troškove (na primer albanski bakar koji je bio trostruko skuplji od njegove cene na svetskom tržištu). Kako je Albanija imala obezbeđenu ishranu žitom iz Jugoslavije nije obraćala dovoljno pažnju na otkup žita u zemlji. Plan otkupa u 1947. ostvaren je kod pšenice sa 75,2\%, kukuruza 37,6\%, raži 86,7\%.

Mešovitim društvima su upravljali samo Albanci, zaobilazeći upravne odbore. Mešovita banka bila je gotovo isključena. Jugoslovenska strana je 1947. odlučila da osim osnovnog kapitala neće učestvovati u udelima u društvu, tako da je sav materijal koji je FNRJ tokom 1947. unela u društva predstavljao udeo Albanije. Usled toga su bilansi društva na kraju godine kao udeo FNRJ pokazivali samo uplaćen osnovni kapital, a na drugoj strani kao nesrazmerno veći udeo Albanije. Za gradnju pruge Drač-Pećin, kako je istakla jugoslovenska strana, sav materijal je došao iz Jugoslavije; 45\% radova na pruzi Drač-Tirana obavljeno je u 1948, izgrađena je hidrocentrala Velika Selita, 1947. otpočeta je eksploatacija naftonosnog polja Patos, veliki broj jugoslovenskih stručnjaka nalazio se u Albaniji. U Jugoslaviji je studirao ili se nalazio na praksi veliki broj albanskih studenata. Celokupan uvoz i izvoz vršen je preko jugoslovenske trgovačke mornarice. U toku 1948. stavljeno je na raspolaganje 5 motornih jedrenjaka ( $50 \%$ ukupne tonaže albanske mornarice) kao i druge manje pomorske jedinice. ${ }^{61}$

${ }^{61}$ AJ, Komisija za međunarodne veze CK SKJ, 507/9, 1/1-127-242; Borba, 6. jul 1948. 
Celokupnu pomoć koju je Jugoslavija pružila od 1945. do sredine 1948. albanska strana je prikazivala kao težnju jugoslovenskih vlasti da eksploatišu prirodna bogatstva Albanije, da njenu industriju preusmere u korist Jugoslavije, kao i da je pretvore u svoju koloniju.

\section{Bilans privredne saradnje FNRJ sa Albanijom}

Na osnovu ugovora o trgovinskog saradnji sa Albanijom 1945. ukupna vrednost isporuka iznosila je 40 miliona dinara. Jugoslavija je isporučila Albaniji 2.991 t pšenice, 5.717 t kukuruza, 106 t pasulja, 2000 t cementa i drugog materijala.

Tokom 1946, pored robne razmene po trgovinskom sporazumu, jugoslovenska vlada je pružila pomoć od 20.000 tona pšenice i kukuruza. Posle poplave sakupljeno je 52.268.441 dinara na ime pomoći. ${ }^{62}$

Jugoslavija je svoje obaveze u toku 1947. i početkom 1948. izvršila sa 1.432.968.000 dinara, isporukama robe. Od značajnijih objekata koji su po kreditu od 2 milijarde dati Albaniji treba navesti: fabriku šećera u Korči, fabriku sardina u Valoni, fabriku marmelade u Elbasanu, štampariju u Tirani, fabriku užarija u Rogožini, automatsku telefonsku centralu u Tirani, kao i veći deo mašina radilica za kompletiranje fabrike rezervnih delova u Tirani. Za potrebe Albanije nabavljena je u Americi jedna predionica pamuka. Pored ovih objekata Albaniji je, između ostalog, isporučeno materijala: železničkih lokomotiva 3 komada, železničkih vagona 69 , automobila 20, ribarskih brodova 3, manjih ribarskih jedinica 10, poljoprivrednih mašina 278, elektromotora 130, raznih mašina 191, plinskog ulja 1500 t, sirovog gvožđa $1.300 \mathrm{t}$, lima $1.100 \mathrm{t}$, veštačkog gnojiva $5.700 \mathrm{t}$, cementa 15.500, stakla $78.000 \mathrm{~m}^{2}$, pamučnog tekstila $5.682 .000 \mathrm{~m}$, vunenog tekstila 259.000 $\mathrm{m}$, cipela 160.000 pari, opanaka 50.000, šećera $800 \mathrm{t}$, marmelade $100 \mathrm{t}$, kukuruza $14.000 \mathrm{t}$, semena pšenice $6.000 \mathrm{t}$, raznog semena $1.500 \mathrm{t}$, lekova za 16.000.000 dinara. ${ }^{63}$

Pored pomoći po kreditu u 1947. vršene su isporuke i u okviru trgovinskog sporazuma, ${ }^{64}$ po kome je Jugoslavija dala ukupno 360.408 .658

${ }^{62}$ AJ, AC SKJ, Ministarstvo spoljne trgovine, 9, 1/1-37; B. Petranović, Jugoslavija, velike sile i balkanske zemlje 1945-1948, 97.

${ }^{63}$ AJ, Komisija za međunarodne veze CK SKJ, 507/9, 1/1-127-242.

${ }^{64}$ Trgovinski sporazum je podrazumevao: Potraživanja NRA: pomoć sakupljena od FNRJ 1946. (50.000.000. dinara), 50\% od akcijskog kapitala za mešovita albansko-jugoslovenska društva (130.000.000), zajam Narodne banke FNRJ Albansko-jugoslovenskoj banci za kreditiranje mešovitih društava 53.000.000 - ukupno 233.000.000 dinara. Transfer ovog novca je trebalo da se izvrši isporukama robe. Predviđena vrednost albanskog izvoza u FNRJ bila je 188.000.000 din. - ukupno 421.000.000 dinara. Potraživanja FNRJ: Predviđena vrednost izvoza FNRJ u Albaniju - 327.000.00 dinara, isporuka robe upotre- 
dinara od čega u robi 289.495.153. Od Albanije je primljeno 153.418.000 leka, od čega u robi $141.123 .750 .{ }^{65}$ Od važnijih artikala po trgovinskom sporazumu Jugoslavija je izvezla: pšenice $20.000 \mathrm{t}$, kukuruza 2.500, šećera $500 \mathrm{t}$, tekstila $752.000 \mathrm{~m}$, marmelade $349 \mathrm{t}^{66}$ Po trgovinskom sporazumu od 1947. Jugoslavija je od Albanije primila ukupno 153.468.000 leka, od toga u robi 141.153.000. Nafta - predviđeno 36.000 t, nije ništa isporučeno, bitumen - predviđeno $26.000 \mathrm{t}$ isporučeno 12.949 , sirovi pamuk $-2.100 \mathrm{t}$ isporučeno 142 , suncokretovo seme $-5.700 \mathrm{t}$ isporučeno $2.011 \mathrm{t}$.

U 1948. Jugoslavija je predvidela pomoć Albaniji u iznosu od 3 milijarde dinara, a jednu milijardu kao prihod od privredne saradnje sa Albanijom. Albanska vlada je angažovala 2.300 miliona materijalom, od čega je 356 miliona predstavljao materijal iz inostranstva.

Do kraja juna 1948, kada je albanska vlada raskinula privredne ugovore, od jugoslovenskih obaveza koje su u prvom polugođu iznosile $779 \mathrm{mi}$ liona izvršeno je 529.635.000 dinara. U tom periodu Jugoslavija je isporučila: antracita 1.700 t, motornog ulja 5.547 t, benzina 717 t, čelika 295 t, poljoprivrednih mašina 721 kom., poljoprivrednih alatki 90 t, kamiona i drugih saobraćajnih sredstava $30 \mathrm{kom}$., sijalica 80.000 kom., elektromotora 22 kom., veštačkog gnojiva $485 \mathrm{t}$, sredstava za zaštitu bilja $256 \mathrm{t}$, vunenih tkanina $126.693 \mathrm{~m}$, pamučnih tkanina $2.462 .579 \mathrm{~m}$, cipela 20.000 pari, gumenih cipela 47.000 pari, opanaka 20.000 pari, marmelade 100 t, šećera 1.500 , čokolade $4 \mathrm{ti} \mathrm{dr.}{ }^{67}$

Na osnovu podataka iz Arhiva Jugoslavije ${ }^{68}$ sačinili smo uporednu tabelu za predratni i posleratni period uvoza i izvoza:

bom robnih čekova u pograničnim krajevima 10.000.000, predviđeni radovi i usluge koje jugoslovenske ustanove i preduzeća treba da izvrše za Albaniju 80.000.000, potraživanja prema Albaniji za 1946. godinu 4.000.000 - ukupno 421.000.000 dinara. Kasnijom procenom kontingentnih lista ustanovljeno je da je vrednost albanskog izvoza 240.121.000, a jugoslovenskog 330.217.000 dinara. Na osnovu stanja na dan 31. decembra 1947. potraživanja FNRJ bila su za isporučenu robu 251.000.000 dinara, za naplaćene robne čekove 353.000, za izvršene radove i usluge 37.000.000 - ukupno 288.353.000 dinara. Potraživanja Albanije: za isporučenu robu 93.000.000, za transfer pomoći poplavljenim, akcijski kapital za mešovita društva i zajam Narodne banke FNRJ Albansko-jugoslovenskoj banci 233.000.000 - ukupno 326.000.000 dinara. Saldo u korist Albanije iznosio je 37.647.000 dinara.

${ }^{65}$ Ova nesrazmera je poticala otuda što je Jugoslavija u okviru trgovinskog sporazuma izvršila u robi transfer akcijskog kapitala za mešovita društva i pomoć postradalima u poplavi. Albanija je, i pored toga, na osnovu salda po sporazumu dugovala Jugoslaviji oko 25 miliona dinara. - AJ, Komisija za međunarodne veze CK SKJ, 507/9, 1/1-127-242.

${ }_{66}^{66}$ AJ, Fond Predsedništva vlade FNRJ, 50, k. 48, 598.

${ }^{67}$ AJ, Komisija za međunarodne veze CK SKJ, 507/9, 1/1-127-242.

${ }^{68}$ AJ, Fond Predsedništva vlade FNRJ, 50, k-48, 16. 


\begin{tabular}{|c|c|c|c|c|c|}
\hline \multicolumn{6}{|c|}{ Albanski uvoz iz Jugoslavije } \\
\hline & \multicolumn{5}{|c|}{ U milionima dinara po cenama } \\
\hline Proizvodna grana & 1938. & 1945. & 1946. & 1947. & 1948. \\
\hline Proizvodnja i prerada uglja & 356 & $/$ & 238 & 590 & 2926 \\
\hline Proizvodnja i prerada nafte & 1 & $/$ & 1 & 24070 & 41236 \\
\hline Proizvodnja crne metalurgije & 1 & $/$ & 1 & 55430 & 5943 \\
\hline Raznobojni metali & 1 & 1 & $/$ & 10893 & 12695 \\
\hline Nemetali & $/$ & 1 & $/$ & 3450 & 336 \\
\hline Crna metalurgija & 30 & 164 & $/$ & 134200 & 20845 \\
\hline Kompletne fabrike & 1 & 1 & $/$ & 42880 & / \\
\hline Brodogradnja & / & 1 & $/$ & 9420 & 928 \\
\hline Elektroindustrija & $/$ & 1 & 342 & 36500 & 3472 \\
\hline Hemijska industrija i lekovi & 801 & 370 & 3500 & 35500 & 31840 \\
\hline Ind. građevinskog materijala & 2133 & 230 & 2940 & 29410 & 15500 \\
\hline Drvna industrija & 40685 & 1 & 7030 & 30000 & 10551 \\
\hline Industrija hartije i celuloze & 7590 & $/$ & 5520 & 64000 & 9481 \\
\hline Tekstilna industrija & 1455 & 1 & 13790 & 371540 & 174205 \\
\hline Koža i obuća & $/$ & 1 & $/$ & 89820 & 15986 \\
\hline Industrija gume & 1 & 1 & $/$ & 15395 & 10371 \\
\hline Prehrambena industrija & 936 & 170 & 1 & 103715 & 61445 \\
\hline Poljoprivreda & 72934 & 6457 & 24537 & 184350 & 31395 \\
\hline Eksploatacija šuma & 10035 & 1 & 1 & 700 & 47 \\
\hline NNO & 1 & 1 & 1 & 332490 & / \\
\hline Razno, ambalaže, troškovi & 1 & 1 & 1 & 112300 & 9200 \\
\hline \multirow[t]{2}{*}{ Filmska industrija } & $/$ & 1 & $/$ & 1420 & I \\
\hline & 136955 & 7331 & 57717 & 1.707 .170 & 458382 \\
\hline
\end{tabular}

U 1948. nisu unete znatne investicione nabavke u mešovita društva: za elektrifikaciju, eksploataciju nafte i eksploataciju železnice. U okviru albanskog uvoza tokom 1938. u daleko najvećem procentu uvezeno je žitarica, zatim proizvoda drvne industrije - nameštaja, rezane građe i furnira, iz industrije papira najveći deo svojih potreba Albanija je podmirila iz Jugoslavije, kao i iz građevinskog materijala - cement. U 1945. i 1946. važno mesto zauzimaju žitarice i tekstilna roba. Naredne, 1947. godine albanska lista potraživanja iz Jugoslavije se proširila po količinama i po asortimanu. Važno mesto pripada i dalje poljoprivrednim proizvodima, a na prvom me- 
stu su tekstilni proizvodi. U albanskom uvozu važno mesto su imali proizvodi prehrambene industrije, šećer i marmelada. Naročito je upadljiva promena kod proizvoda metalne industrije u odnosu na predratni period. Dok su pre rata proizvodi metalne industrije sasvim neznatno učestvovali $u$ albanskom uvozu, u 1947. zauzimaju treće mesto u ukupnom albanskom uvozu.

Albanski izvoz u Jugoslaviju se posle rata povećavao iz godine u godinu. Najvažnija stavka u izvozu 1948. bilo je maslinovo ulje, zatim sirova nafta, bitumen, likeri, masline za jelo, morska so i drugo. Obim i kretanje albanskog izvoza pokazuje sledeća tabela: ${ }^{69}$

\begin{tabular}{|c|c|c|c|c|c|c|c|c|c|c|}
\hline \multicolumn{11}{|c|}{ Albanski izvoz } \\
\hline & \multicolumn{2}{|c|}{1938.} & \multicolumn{2}{|c|}{1945.} & \multicolumn{2}{|c|}{1946.} & \multicolumn{2}{|c|}{1947.} & \multicolumn{2}{|c|}{1948.} \\
\hline Artikal & 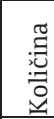 & 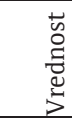 & 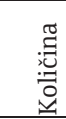 & 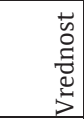 & 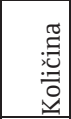 & 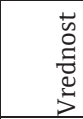 & 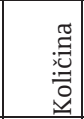 & 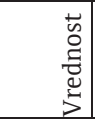 & 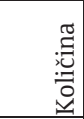 & 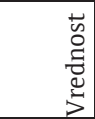 \\
\hline Nafta sirova & 1 & 1 & & 1 & 95 & 409 & 1 & 1 & 40390 & 50487 \\
\hline Solarno ulje & 1 & 1 & 2516 & 2113 & 1 & 1 & 1 & 1 & 1 & \\
\hline Benzin & 1 & 7 & 437 & 855 & 60 & 82 & & 1 & 7 & 7 \\
\hline Bitumen & 1 & 1 & 1 & 1 & 1558 & 1917 & 13000 & 24300 & 8300 & 16000 \\
\hline Ostali katran proizv. & 13 & 13 & 1 & 1 & 344 & 703 & & 1 & 1 & \\
\hline Bakar blister & 1 & 1 & 1 & 1 & 1 & 1 & 1 & 1 & 170 & 9350 \\
\hline Hromna ruda & 1 & 7 & & 1 & 1 & & 1 & $\pi$ & 3000 & 3600 \\
\hline So morska & 7 & 7 & 146 & 188 & 3762 & 13496 & & $\pi$ & 2000 & 5950 \\
\hline Staro gvožđe & 125 & 221 & 1 & 1 & 1 & & 7 & 1 & 1 & 1 \\
\hline Radio aparati kom. & 1 & 1 & 1 & 1 & 500 & 1072 & 7 & 1 & 1 & 1 \\
\hline Sapun običan t & 1 & 1 & 4 & 190 & 48 & 649 & 1 & 1 & 1 & 1 \\
\hline Tanin & 1 & 1 & 1 & 1 & 1 & & 30 & 176 & 1 & 1 \\
\hline Kože goveđe kom. & 1 & 1 & 1 & 1 & 705 & 24129 & 1 & 1 & 1 & 1 \\
\hline Kože jagnjeće kom. & 30 & 930 & 1 & 1 & 1 & & 710 & 30243 & 36 & 1116 \\
\hline Masline t & 1 & 1 & 1 & 1 & 1 & 1 & 370 & 9814 & 6 & 156 \\
\hline Likeri-zalihe & 887 & 800 & 1 & 1 & $\pi$ & 1 & 1 & 1 & 1300 & 1287 \\
\hline Creva km & 1 & 1 & 1 & 1 & 1 & 1 & 1 & 1 & 400 & 40000 \\
\hline Duvan rezani t & 7 & 7 & 7 & 1 & 1 & 1 & 7 & $\pi$ & 660 & 990 \\
\hline Cigarete t & 1 & 1 & 1 & 1 & 1 & 1 & 12 & 5427 & 1 & 1 \\
\hline Suncokretovo seme t & 5 & 425 & 7 & 1 & 1 & 7 & 2000 & 12448 & 7 & 7 \\
\hline Pamuk sirov t & 1 & 1 & 1 & 1 & 1 & & 170 & 12400 & 1 & \\
\hline Masline za ulje t & 1 & 1 & 1 & 1 & 1 & & 1 & 1 & 5620 & 36000 \\
\hline Vuna domaća $t$ & 1 & 1 & 1 & 1,2 & 321 & 13295 & 496 & 23350 & 1 & \\
\hline Vuna strana $t$ & 1 & 1 & 1 & 1 & 1 & & 300 & 16814 & 1 & \\
\hline Masline soljene t & 1 & 1 & 1 & 1 & 1 & 1 & 1 & 1 & 370 & 5091 \\
\hline Južno voće t & 1 & 1 & 1 & 1 & 1 & 1 & 23 & 494 & 169 & 11000 \\
\hline Maslinovo ulje t & 1 & 16 & 11 & 579 & 49 & 1767 & 1 & 1 & 2000 & 73200 \\
\hline Vino $t$ & 1 & 1 & 1 & 1 & 1 & 1 & 1 & 1 & 75 & 2000 \\
\hline Zečje kože kom. & 7 & 7 & 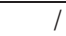 & 1 & 1 & & 79 & 454 & 11,3 & 248 \\
\hline Koža divljači kom. & 1 & 7 & & 1 & 1 & & 7 & 1 & 8500 & 1757 \\
\hline Ostalo kom. & 7 & 356 & 1 & 7184 & 7 & 1079 & 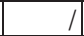 & 5200 & 1 & 1000 \\
\hline Vrednost u 1000 din. & 7 & 2761 & & 11110 & & 59048 & & 141120 & 7 & 259232 \\
\hline
\end{tabular}

${ }^{69}$ AJ, Fond Predsedništva vlade FNRJ, 50, k-48, 18. 
Albanski izvoz se svodio na sirovu naftu, bitumen, masline, maslinovo ulje, komine od maslina, morsku so, sitnu kožu, kožu od divljači i nešto hroma i bakra. Svi ostali artikli koje je albanska privreda mogla da ponudi stranim tržištima bili su neznatni zbog vrlo slabog asortimana i kvaliteta (suve šljive, suve smokve, soljena creva), teških transportnih prilika u zemlji (bakar, hrom, mazut, mazut, razne vrste trupaca) ili zbog nedostatka odgovarajuće ambalaže (luk, lekovito bilje, vino, južno voće).

Rezultati ekonomske saradnje Jugoslavije i Albanije u posmatranom periodu, prema dostupnim podacima, mogu se sumirati na sledeći način:

\begin{tabular}{|c|c|l|}
\hline Godina & Kredit Jugoslavije & \multicolumn{1}{c|}{ Ostvarena pomoć } \\
\hline 1945. & 1.200 .000 dinara & 40 miliona dinara \\
\hline 1946. & $\begin{array}{l}\text { Pomoć posle poplave: 52.268.441 dinara } \\
1.551 .226 .87 \text { (NRA - Jugoslaviji) } \\
1.303 .879 .81 \text { (FNRJ - Albaniji) } \\
\text { saldo u korist Albanije 247.347.06 }\end{array}$ \\
\hline 1947. & 2.000 .000 .000 dinara & $\begin{array}{l}1.356 .811 .698 .49 \text { dinara } \\
\text { od Albanije primljeno 150.000.000 }\end{array}$ \\
\hline 1948. & $\begin{array}{l}\text { 3.000.000.000 dinara } \\
\text { do kraja juna 779 miliona } \\
\text { dinara }\end{array}$ & 529.635 .000 dinara \\
\hline Ukupno & & Oko 2.247.391.128 dinara \\
\hline
\end{tabular}

Božica Slavković

THE YUGOSLAV-ALBANIAN ECONOMIC RELATIONS 1945-1948 Plans and Cooperation

\section{Summary}

Yugoslavia and Albania in 1945 launched an economic and political cooperation, culminating in 1946. Yugoslavia, despite their impoverishment after the war, decided to assist Albania in all fields. Albania has received new factories, roads, railways, electricity, postal and transport, food and help her when it was most needed. However, in mid 1947 Albania turned to Moscow and tried to get help from the USSR. To a complete deterioration of relations between Yugoslavia and Albania came after the signing of a Resolution-IB, which Albania joined when she broke all the treaties with Yugoslavia. 